International Review of Research in Open and Distributed Learning Volume 16, Number 5

\title{
Open Educational Resources in Canada 2015
}

Rory McGreal, Terry Anderson, and Dianne Conrad

Athabasca University

\begin{abstract}
Canada's important areas of expertise in open educational resources (OER) are beginning to be built upon or replicated more broadly in all education and training sectors. This paper provides an overview of the state of the art in OER initiatives and open higher education in general in Canada, providing insights into what is happening nationally and provincially. There are growing examples of OER initiatives from several Canadian institutions offering free courses to Canadians and international learners. National open education initiatives include the federal government's Open Data pilot project and the Council of Ministers of Education of Canada (CMEC) support for the Open Educational Resource Paris Declaration, as well as Creative Commons Canada. Regionally, the western provinces of British Columbia and Alberta are supporting OER as part of major open education initiatives.
\end{abstract}

Keywords: open educational resources, OER, Canada, MOOC, policy

\section{Introduction}

The concept of open education includes the provision of activities for educators, programs to support not only the development of OER but also MOOCs (Massive Open Online Courses), and for research and development initiatives to ensure effective practices. However, despite a growing body of literature and public opinion supporting the economic, social, and political benefits of open education, there remains a need for the development and implementation of policies at government and institutional levels in order for OER to become fully active (D'Antoni, Hylen \& Van Damme, 2012; Dhanarajan \& Abeywardena, 2013; European Parliament, 2014; van der Vaart, 2013). This paper presents a pan-Canadian overview of key government and institutional 
practices designed to support OER initiatives and enhance openness in many areas in postsecondary education. This overview maps significant initiatives with the aim of sharing and promoting more vigorous policies designed to maximize OER development using open education practices in Canada. Canada has important areas of expertise in open education, mostly at the post-secondary level, which is beginning to be built upon or replicated more broadly in all education and training sectors. Although there is no federal government strategy specifically supporting open educational practices at present, there has been activity at the provincial level in Western Canada. There are few other signs of any significant initiatives or policy designed to support OER development and open practice-related activity across Canadian governments, institutions or industry. OER development and open initiatives in Canada have tended to focus at the level of individual institutions and concentrate on access and availability issues as opposed to development of practice and policy and/ or initiatives to encourage openness.

\section{Background and History of OER Development in Canada}

Canada is unique in the world in that it is the only country whose national government has no authority in education; in Canada, education is exclusively a provincial responsibility. The federal government can, however, intervene in other areas relevant to open education. For example, there is a federal program underway to promote the growth of the open data movement through a new open data licence (Scassa, 2012). This program introduces an open data pilot project to businesses and citizens with three streams: open data, open information and open dialogue, supporting innovation and leveraging public information to support commercialization and research (Government of Canada, 2015).

At the provincial level, the province of British Columbia has also undertaken open initiatives that provide public access to government information and data, giving citizens opportunities to collaborate on matters such as policy and service delivery. Its open government license enables use and reuse of government information and data.

The concept and activities of openness are clearly evident in the many Canadian universities and community colleges developing programs and policies to broaden open access and designing, developing and building learning object repositories. Athabasca University, Memorial University, Concordia University and the University of Calgary are examples of institutions that are becoming more familiar and comfortable with the concept of open access and are actively sharing scholarly research and data through university repositories. They also provide author funding to assist researchers with open access fees. They are working to minimize or avoid open access fees levied by publishers. Universities are also promoting openness through the use of Canadian Creative Commons (CC) licenses. 
Athabasca University (AU) has been a leader in open educational resources (OER) and is sometimes referred to as Canada's "First OER University." AU was also the first Canadian institution to adopt an open access policy in 2006, revised in 2014, that recommends that faculty, academic, and professional staff deposit an electronic copy of any published research articles, which have been elsewhere accepted for publication, into an AU repository. In 2009, the University of Ottawa adopted an open access program supporting free access to their scholarly research. Some of the initiatives in its open access program include a promise to make accessible for free, through an online repository, all its scholarly publications; an author fund designed to minimize open access fees charged by publishers; funding for the creation of digital educational materials accessible by all online, for free; and a commitment to publish a collection of open access books and research funds to continue studies on open access.

Open initiatives also include support for open university presses such as AUPress at Athabasca University and limited open titles from the University of Ottawa Press and other university presses.

Other universities are following suit. The University of Toronto/OISE, for instance, adopted a formal policy on open access in March 2012 (OISE, n. d.) referencing the Open Data pilot, a Government of Canada initiative. Nonetheless, while the concepts of openness and open access appear to be gaining considerable ground, and in spite of the apparent endorsement by government, their growth, similar to that of OER, is threatened by a lack of public funding.

While openness can be seen as a growing trend, specific or detailed Canadian OER initiatives, in many sectors, are difficult to isolate. Few Canadian institutions are visibly working on open practices and/or policy development, although, the western region of Canada does have real projects and initiatives in progress and is engaged in assembling, developing and using OER.

However, there are some initiatives that support the notion of OER growth and acceptance at a national level. The following section discusses the creation and implementation of open data use in Canada, Creative Commons Canada, the role of the Council of Ministers of Education of Canada (CMEC), and the Tri-Agency Open Access Policy.

\section{OER Initiatives in Canada}

The OER movement in Canada can be categorized in several different ways, from type-ofinitiative, to geographical location, to institutional initiative. The initiatives described below are categorized accordingly. 


\section{Pan-Canadian Initiatives and Organizations}

Open Data. The Canadian government has initiated an Open Data pilot project using an open government license, which is similar to the Creative Commons attribution license allowing for remixing and non-commercial uses. And in April 2014, Industry Canada launched Digital Canada 150, which aims to support "connecting, and protecting Canadians, economic opportunities, digital government and Canadian content". CANARIE is a federally funded corporation that is "a vital component of Canada's digital infrastructure supporting research, education and innovation"(CANARIE, n.d.). Along with National Research Council Knowledge Management and the Canadian Association of Research Libraries, CANARIE supports Research Data Canada in "ramping up" its activities to meet researcher needs in the co-ordination and promotion of research data management. The strategy includes developing open science and open data to facilitate open access to publications and related data resulting from federally funded research in easily accessible formats.

Creative Commons (CC) Canada. Born of the global open education movement, the creation and use of OER benefits from the development and use of Creative Commons licences which provide the legal framework to share these resources. A non-profit organization, CC Canada supports, a legal and technical infrastructure for openness It has created a set of free licensing tools permitting authors/ developers to share, reuse, and remix materials (including, but not limited to OER) with an explicit "some rights reserved but others clearly allowed" approach to copyright. As an affiliate of the larger body, CC Canada is a collaborative initiative comprising the Samuelson Glushko Canadian Internet Policy and Public Interest Clinic (CIPPIC) at the University of Ottawa, BCcampus and Athabasca University.

In addition to helping users choose licenses and find CC-licensed work, CC Canada is a proponent of open government and the philosophy that government data should be accessible, shareable, and re-usable under open licenses by everyone. It is actively involved in this pursuit, studying how CC licenses can be used by governments to make data available freely for public use. Another CC Canada project is being spearheaded by its legal team at CIPPIC, which is researching the development of user-friendly tools that will provide comprehensive knowledge to users on how to analyze and use different open licenses. CC Canada has also launched a series of conferences, or salons, across the country in order to raise awareness of CC and its potential among different constituencies including educators, writers, and artists. In May, 2014, Robin Merkley, a Canadian, was appointed CEO of Creative Commons worldwide.

Council of Ministers of Education, Canada (CMEC). CMEC is an organization comprising 13 provincial and territorial ministries of education. In response to the UNESCO Paris Declaration on OER, OER were discussed for the first time at a national meeting in 2012. The Ministers "reaffirmed their commitment to open access to knowledge and education and to 
the need to adapt teaching and learning practices to the new realities of the information age" (CMEC, 2012). The Declaration was followed by discussions at CMEC, who met in 2013 in Iqaluit, Nunavut, and unanimously endorsed the Paris Declaration. This Declaration has played an important role in the growing support for OER across Canada and has been instrumental in the establishment of OER initiatives in the three western provinces

Tri-Agency Open Access Policy. The three Canadian research funding agencies the Canadian Institutes of Health Research (CIHR), the Natural Sciences and Engineering Research Council of Canada (NSERC) and the Social Sciences and Humanities Research Council of Canada (SSHRC) - have agreed on a draft policy supporting open access in scholarly publications. These agencies strongly support knowledge sharing and mobilization as well as research collaborations domestically and internationally, and so understand the importance of open access supporting the free exchange of knowledge.

\section{Collaborations - National and International.}

There are also several examples of specific OER initiatives in Canada that feature national and international collaboration. OER universitas, particularly, is unique in its breadth and scope.

OER universitas. OER universitas $(\mathrm{OERu})$ offers free online university courses in collaboration with Canadian partners so that learners can gain formal credentials from the partner institutions. OERu is a consortium of more than 36 institutions and several organizations on five continents. It is dedicated to widening access and reducing the cost of post-secondary education for learners internationally by providing OER pathways to achieve formal credible credentials (McGreal, Mackintosh \& Taylor, 2013). There are seven members of the OERu located in Canada: three universities (Athabasca, Thompson Rivers and Kwantlen); one community college (Portage College in Alberta); and three organizations (BCcampus, eCampus Alberta, and Contact North in Ontario).

BCcampus. BCcampus, arguably the most active collaborative Canadian organization in the open practices arena, is a publicly funded service which has turned to open concepts and methods to create a sustainable approach to online learning for BC's public post-secondary institutions. BCcampus was created to enhance students' ability to not only identify, choose, register for, and take courses but also to apply any academic credits earned to credentials at a selected home institution; it was also intended to benefit institutions through the rationalization of demand for academic opportunities from students with the supply of online courses from BC's public post-secondary institutions.

BCcampus has been the leader in Canada in promoting OER with CMEC. BCcampus also played a major role in the British Columbia Ministry of Advanced Education, Innovation and Technology's (MAE) decision to support and implement the Open Textbook Project, which started with a commitment to 40 open textbooks at the post-secondary level and is now committed to 60 
(BCcampus, 2014). BCcampus hosted a working forum on OER for senior post-secondary institution representatives in Vancouver in October, 2012 with the objective of developing a common understanding of what OER could mean for BC and building a shared vision of how to develop and use them. The session also studied ways that $\mathrm{BC}$ could take advantage of the promise of OER and specifically, open textbooks.

The BCcampus Shareable Online Learning Resources repository (SOL*R) enables the licensing, contribution, and access to free online teaching and learning resources. Specifically, in support of OER, other BCcampus initiatives are underway. This includes the major Open Textbook Project described above. Another initiative is the implementation of an OER initiative around apprenticeships for the trades in partnership with BC's Industry Training Authority. BCcampus is also working with the North American Network of Science Labs Online (NANSLO), building on the success of the Remote Web-based Science Laboratory (RWSL) and open educational science courseware.

\section{Institutional Initiatives}

Athabasca University. There has been, and continues to be, significant OER activity at Athabasca University. AU was the first university in Canada to join the Open Courseware Consortium, now the Open Education Consortium (OEC), and as of 2014, remains the only Canadian institutional member. The province of Alberta and AU were chosen to host the 2015 OEC Conference which was successfully held in Banff with over 250 delegates from more than 26 countries around the world. AU was also given an OEC ACE Award in 2014 for its highly visible OER research website, the OER Knowledge Cloud. AU has also made courses and course modules available on its OEC site.

AU is home to the Technology Enhanced Knowledge Research Institute (TEKRI)) and the UNESCO/COL/ ICDE Chair in OER, both of which promote research into and the implementation of OER at institutional, national, and international levels. The OER Knowledge Cloud was created as a goal of the Chair initiative. The OER Chair is also a member of the board of the OER Foundation, which hosts the OER universitas (OERu).

AU's adoption of open access began with the creation of the scholarly journal, International Review of Research in Open and Distributed Learning (IRRODL) in 1999 and continued in 2005 with the implementation of AUSpace, a DSpace repository of scholarly articles, theses, and other documents produced within the AU community. In addition, Athabasca's AUPress was the first open access university press in Canada, starting in 2010, and currently offers over 100 volumes. Other AU open initiatives include participation in workshops and conferences, conducting a mapping of open educational activities with POERUP and eMundus Europrojects, and supporting GO-GN, the Global OER Graduate Network. 
Thompson Rivers University (TRU) Open Learning. TRU houses the former BC Open University as its distance education wing, called TRU Open Learning. It is working with several OERu partner institutions providing initial prototype courses to be released as OER. TRU Open Learning, like AU, has a robust PLAR system that includes challenge examinations and transfer of credit, which makes it a key partner for OER initiatives nationally and internationally.

OCAD University. The Inclusive Design Research Centre, a research and development centre at OCAD University in Ontario, consists of an international community of open practice advocates. The learning technologies and products that have been developed and distributed by IDRC are distributed under the GNU General Public License. This means that the code is open source and requires users to share products with the same liberal licensing that they have acquired it.

A key project, FLOE (Flexible Learning for Open Education), is currently one of the Centre's biggest initiatives. It has received substantial funding from the Hewlett Foundation and the European Commission. FLOE takes advantage of the fact they have a set of curricula that is openly licensed that can be repurposed and reused to make content accessible. This makes FLOE heavily dependent on OER which presents an optimal learning environment to meet the needs of all learners, including those with disabilities. FLOE advances the strengths and values of open education and encourages pedagogical and technical innovation. FLOE also promotes OER for their content portability, ease of updating, internationalization and localization, content reuse and repurposing, and more efficient and effective content discovery. FLOE's work is international and broad; to support adoption in Africa and other areas where mobile devices are more prevalent than Internet access, FLOE creates tools and services for delivery as OER via audio, text messages, and the small screens found on popular cell phones. These same tools and services are intended to support accessibility through inclusive design.

Contact North/Contact Nord (CN/CN). CN/ CN is Ontario's distance education and training network. It works to provide programming from public colleges, universities, and schools with a focus on smaller towns, rural, and remote communities. In 2011, Contact North published “Open Educational Resources (OER) Opportunities for Ontario," which is a major position paper on OER which "set(s) out the case for the implementation of an Ontario OER initiative (Contact North, 2011). Contact North has also published an OER primer as a video series.

Téléuniversité du Québec (TÉLUQ). TÉLUQ has a policy on the dissemination of educational resources, the Politique de gestion de la diffusion des ressources d'enseignement et d'apprentissage (REA). These policies relate to learning content in general and could include OER, but are also designed for proprietary content. Because TÉLUQ faculty retain the intellectual property of all original material they produce for teaching, institutional policy has limited impact on what professors do with their material. The LICEF, Laboratoire en Informatique Cognitive et 
Environnements de Formation, is a research centre at TÉLUQ which hosts the Banques des ressources éeducatives en réseau (brer), a repository of French language OER.

\section{A Movement toward OER Policy}

The most important development in Canada for the open movement to date has been the triprovince Memorandum of Understanding on Open Educational Resources. The three western provinces of Alberta, British Columbia, and Saskatchewan have agreed to cooperate on the development of common OER. This agreement includes cooperation among the provinces in sharing and developing OER; identifying, sharing and encouraging the use of OER; and by using technology, foster an understanding of OER issues. The MOU initiative was led by the British Columbia Ministry of Advanced Education, Innovation and Technology (MAE), and influenced by BCcampus, as described above. The role of each other partner province is outlined below.

Following from the 2012 MOU, the Alberta Ministry of Advanced Education and Innovation announced an OER initiative, pledging \$2 million for OER development, promotion, and sharing. This program provides publicly funded post-secondary institutions within the province of Alberta with support for the assembly, use, development, implementation, and evaluation of OER to support teaching, learning, and research.

Previously, Alberta, without making direct commitments, had been actively supporting OERrelated initiatives for several years. In 1999, the Campus Alberta Repository of Educational Objects (CAREO) was funded to promote the sharing of open learning resources within Alberta. Unfortunately, these initiatives were not funded after the initial investment and eventually were closed. Another limited project that is still extant is the Alberta Core (Collaborative Online Resource Environment) and the LearnAlberta.Ca site at the K-12 level. These are limited quasiopen initiatives, restricting the openness on some resources to provincial or institutional teachers, students, and parents. The CanCore Learning Metadata Resource Initiative was yet another early open education initiative in Alberta, which resulted in the creation of metadata implementation standards for learning objects in 2006.

Through its Access to the Future Program, the Alberta Department of Enterprise and Advanced Education has been financially supporting OER initiatives at Athabasca University. These include a project to promote OERs within the university and search out and identify reusable objects for courses and support for the AU UNESCO/COL/ICDE Chair in OER, who is charged with promoting the use of OER institutionally, provincially, and internationally.

The government of Saskatchewan, as of J une 2014, has been working on an OER open textbook initiative for Saskatchewan's universities and colleges. It has been heavily lobbied by student groups and has been following the initiatives in $\mathrm{BC}$ and Alberta closely.

This work is licensed under a Creative Commons Attribution 4.0 International License. 


\section{Ontario and Quebec}

Ontario is Canada's largest province in population with approximately 16 million inhabitants. However, to date there is no evidence that any provincial policy related to open practices is being considered. On the contrary, their recently announced "Ontario Online," a collaborative Centre of Excellence in technology-enabled learning, does not support OER development. Their "Shared Online Course" \$8.5 million fund supports restrictively licensed resources rather than open access content.

Quebec, Canada's French-speaking province, has differed from other provincial governments regarding copyright protection in education and so has not been inclined to be supportive of OER initiatives. Quebec, as Canada's only officially unilingual province, has a thriving local Francophone cultural industry, unlike the Anglophone provinces that tend to rely on American cultural imports. The protection of the French language culture in Quebec is a paramount concern, and as such, their government is much more concerned about protecting their publishers and authors than they are about supporting open content for their educational institutions. They officially and legally use the term droit d'auteur (author's rights) to translate the term "copyright" rather than the more precise droit de copie (copy right). This is more in keeping with the European custom emphasizing the rights of the publishers and authors over the rights of learners and other consumers. Membres du Comité sur le droit d'auteur de l'Association nationale des éditeurs de livres (Members of the committee on author's rights (copyright) of the National Association of Book Editors) have been particularly vocal in expressing their opinions in support of strict copyright regulations. And the Quebec government, of all the provincial governments, has been alone in wanting to limit the fair dealing exemption to copyright.

However, perhaps leading to a recommandation by the Organisation internationale de la Francophonie, whose conference was hosted in February 2013 in Moncton, New Brunswick, Canada, there is renewed interest in Québec in the promotion of des ressources éducatives libres (OER). The Ministère de l'Éducation, du Loisir et du Sport du Québec is financing the website brer (banques de ressources éducatives en réseau), which hosts French language OER. THOT CURSUS is another Québec organization that has implemented an OER repository accessible through a website.

\section{MO0Cs (Massive Open Online Courses)}

MOOCs grew out of the open education movement and, as such, represent an important part of the OER landscape. Yuan and Powell (2013) describe how MOOCs developed out of the open education, open source, open access, open educational resource movements, although there are 
also commercial versions of MOOCs now in operation, such as Udacity and Coursera. Weller (2014) sees MOOCs (at least the non-commercial ones) "as part of a continuum" that proceeded from open source, to open access to OER, and open practices. MOOCs provide perhaps the clearest case for the argument that openness has been successful.

Despite their 'open heritage' many MOOC suppliers specifically do not open or license the student learning content created or used in the MOOC. This transfer of ownership of copyright material from university or faculty to commercial MOOC suppliers can be a source of friction. Further, the restriction of access to materials results in less optimal re-use or adaptation of MOOC content than wished for by many educators.

\section{MOOCs' Canadian Roots}

MOOCs are Canadian in origin. The name dates to an experimental course led by George Siemens at the University of Manitoba and Stephen Downes at the National Research Council in 2008 (Tamburri, 2014). They taught a regular online university credit course, Connectivism and Connective Knowledge (Downes \& Siemens, 2014) with 25 students; and more than 2,200 additional learners joined the course online. As Siemens reports, this course, delivered in 2008, was the first MOOC, to combine open content with open teaching. This concept was developed from the idea of an open Wiki pioneered by David Wiley at Utah State University and an open session on social media in which international guest experts led discussions, implemented by Alex Couros at the University of Regina (Siemens, 2012).

"The MOOC is open and invitational" (McAuley, Stewart, Siemens, \& Cormier, 2010). Anyone can participate and learners determine for themselves the extent of their participation. This decision may be based on personal interest, workplace requirements, academic goals, or other reasons. This level of openness allows many people to participate who may otherwise be unable to access learning.

In 2011, Sebastien Thrun at Stanford University delivered a MOOC on Artificial Intelligence to more than 100, 000 learners. However, this MOOC was more teacher-centric than Siemens and Downes' original connectivist MOOC.

CMOOCs and xMOOCs. Downes coined the term cMOOC to describe their original course - the "c" stands for "connectivist." The goal of cMOOCs was to use the Internet to create an extended network of learners who while generating content and reflections learn from one another. David Cormier at the University of Prince Edward Island is continuing this tradition with a pre-university level MOOC, ExperienceU or XPU. On the other hand, Downes labelled the new instructivist courses xMOOCs (Downes, 2013). Recent xMOOCs continue to export the "sage on the stage" lecturing model of classroom learning to the online world (now delivered largely by video clips). 
xMOOCs have become the predominant form of MOOC delivery in Canada, with more than 320 MOOCs currently being offered by Canadian institutions or individuals. Most of these course are provided by top-tier traditional institutions using the commercial Coursera platform (McMaster University, University of British Columbia, University of Toronto); or the non-profit EdX platform (McGill University, University of Alberta, University of British Columbia, University of Toronto). Others, mainly middle-tier institutions use the openly-licensed CanvasNet platform (Dalhousie University, Royal Roads University, Athabasca University, and the University of Saskatchewan). Udemy is a for-profit company that hosts a platform for independent instructors, who offer their own MOOCs. To date, there is only one such course delivered from Canada. Wide World Ed is a Canadian grassroots organization that has tried to implement some homegrown Canadian MOOCs "for the public good" with limited success. There are also several self-published MOOCs. (See https:// www.mooc-list.com/ countrys/ canada)

\section{Development of MOOC Culture in Canada}

There are several identifiable bastions of MOOC activity in Canada. As previously noted, Athabasca University faculty were significant contributors to the first MOOC in 2008. Following that, AU faculty members Siemens and McGreal delivered the university's first cMOOC in 2013 on open education. This course could be described as an "embedded" MOOC because it was based on and delivered with a for-credit Master of Education course in AU's Centre for Distance Education. The MOOC learners followed the same course materials, but they were separated from the enrolled students. However, the experiment proved unsuccessful as synergies between the two groups suffered from the separation. In 2015, the AU MOOC, "Learning to Learn Online," was delivered to more than 3,000 learners.

Based in Vancouver, British Columbia, the Commonwealth of Learning (COL) is charged with promoting open education throughout the 53 countries of the Commonwealth. In 2013, in collaboration with the Indian Institute of Technology, Kanpur (IITK), they delivered a MOOC on Mobiles for Development to more than 2,000 learners from 116 countries including many nonCommonwealth countries, for example in Eastern Europe using a modified model of the cMOOC on Sakai's open source platform and developing appropriate OER as YouTube videos (Reporter, 2014). Their MOOCs for Development Project has been very successful and the MOOC on Mobiles for Development received the Open Education Award 2015 under the category "open MOOC" from the Open Education Consortium. Meanwhile, COL announced the launch of a MOOC Platform as a service to developing countries of the Commonwealth. The platform is based on the mooKIT, developed by the IIITK, can be used by institutions to deliver MOOCs within a short time (less than an hour) and customize it for immediate launch. The platform comes with a student registration management system (up to 10,000 sign-ups), a full-fledged forum for multiple threads, a module to receive audio via phone (should video streaming become difficult), a learning analytic module, a document repository for reading materials, and a module to produce a variety of tests. Most important is the advanced integration of Twitter and Facebook with this 
platform. Learners can access all the discussions via the Twitter or Facebook accounts and can post their queries/ comments directly from these social media spaces (Personal communication, V. Balaji, COL).

Alberta's largest university, The University of Alberta, a bi-modal institution, delivered Canada's first xMOOC, Dino 101: Dinosaur Paleobiology in 2013. This offering could also be considered a type of embedded MOOC as it provided two options, a free, non-credit learning experience or a paid, for-credit course.

Access to content on the Internet, either as an OER or otherwise open content, and the emergence of MOOCs as an recent phenomenon, has opened up opportunities for learning for users not just in Canada but internationally. This new type of learning raises the question that is being addressed by the OERu: How can this learning be recognized? Canadian open institutions such as Athabasca University and Thompson Rivers University have a history of assessing and accrediting these informal modes of learning either through portfolios and systems of prior learning assessment or through challenge for credit examinations.

The recognition of prior learning (RPL) or prior learning assessment and recognition (PLAR) represents another facet of openness in that it is another way that students can gain accreditation and credit for learning. Adults can works toward and earn degree credit for their learning from several universities in Canada (e.g. Athabasca University, Thompson Rivers University) drawing on their non-formal learning (training and participation in workshops), or informal and experiential learning gained from the workplace or other life experiences. Achieving formal credits in this way can reduce the number of courses that a student needs to complete a degree program and also cut times and costs. On the downside, as is also the case with other nods to openness, RPL/PLAR processes are not as yet as widely recognized among traditional institutions.

Challenge for Credit, another way in which some institutions evaluate student learning, can also be considered a form of RPL/ PLAR. Challenge for credit consists of a challenge examination or other form of assessment, allowing students an opportunity to demonstrate their proficiency in the subject matter and skills of a specific course without actually taking the course. Credit transfer among Canadian institutions is also becoming more widely accepted, thus promoting virtual mobility.

\section{Conclusion}

In this paper we have documented efforts, policies and programs that are designed to address innovation; visibility of adoption by others; and the capacity for potential adaptors to make trial applications of the innovation (Rogers, 2013) in the public post-secondary sector. Specifically, we have focused on the action of governments and institutions to provide incentives for the development and trialing of OER in the form of textbooks and scholarly publications and the 
development of the open education movement that supports MOOCs.

Efforts by research funding organizations, open scholarly presses, and research databases have been designed to determine and demonstrate relative advantages of open education from both pedagogical and economic perspectives. In large and complex countries with diverse educational institutions, especially in a confederation such as Canada, where, as previously mentioned, each province has total autonomy in education, it is difficult to be aware of many varied practices and policies that are emerging. While other countries can develop national policies, it is possible in Canada to develop trans-Canadian provincial partnerships but these partnerships operate without national government involvement.

The implementation of open education in Canada remains in its early stages. However, the growing interest in MOOCs, the recent OER initiatives, and the inter-provincial partnership MOU in Western Canada could well be harbingers of future cooperative and/or collaborative developments in Canada, placing it on a fast track to national collaborations, policy, and standards in open education.

\section{Acknowledgments}

The authors would like to acknowledge the support of the eMundus project of the Erasmus Mundus and the POERUP programmes of the European Commission.

\section{References}

BCcampus. (2014, February 20). 5 questions with Mary Burgess on our open textbook project and the future of open education. Retrieved from http:// bccampus.ca/2014/02/20/5questions-with-mary-burgess-on-our-open-textbook-project-and-the-future-of-openeducation/

CANARIE. (n. d.). Canada's ultra-high-speed National Research and Education Network. Retrieved from http://www.canarie.ca/

Contact North. (2011, October). Open educational resources (OER) opportunities for Ontario. Retrieved from https:// oerknowledgecloud.org/ ?q=content/ open-educational-resourcesoer-opportunities-ontario

D'Antoni, S., Hylén J., Mulder F., \& Van Damme D. (2012). Open educational resources: Analysis of responses to the OECD country questionnaire. Retrieved from http://www.oecdilibrary.org/ open-educational- 
resources 5k990rjhvtlv.pdf?contentType=/ns/WorkingPaper\&itemId=/content/ working paper/5k990rjhvtlv-en\&containerItemId=/ content/ workingpaperseries/

Dhanarajan, G. and Abeywardena I. S. (2013). Higher education and open educational resources in Asia: An overview. In G. Dhanarajan \& Porter D. (Eds.), Perspectives on open and distancelearning: Open Educational Resources: An Asian perspective. Vancouver: Commonwealth of Learning. Retrieved from http:// www.col.org/resources/publications/Pages/ detail.aspx?PID=441

Downes, S. and Siemens, G. (2008). Connectivism and connective knowledge. The Daily Archives. Retrieved from http:// connect.downes.ca/

Downes, S. (2013, April 9). What the 'x' in 'xMOOC' stands for [Blog]. Retrieved from https:// plus.google.com/ +StephenDownes/posts/LEwaKxL2MaM

European Parliament. (2014). On new technologies and open educational resources A70249/2014. Retrieved from http:// www.europarl.europa.eu/sides/getDoc.do?type=REPORT\&mode=XML\&reference =A7-2014-0249\&language=EN\#title3

Government of Canada. (2015). Open Government. Retrieved from http://open.canada.ca/en

McAuley, A., Stewart, B., Siemens, G., \& Cormier, D. (2010). The MOOC model for digital practice. Retrieved from http:// www.elearnspace.org/Articles/MOOC_Final.pdf

McGreal, R., Mackintosh, W., \& Taylor, J . (2013). Open educational resources university: An assessment and credit for students initiative. In R. McGreal, W. Kinutha, \& S. Marshall (Eds.). Open Educational Resources: Innovation Research and Practice. Vancouver: Commonwealth of Learning. Retrieved from http://www.col.org/ PublicationDocuments/pub_PS_OER-IRP_web.pdf

OISE. (n. d.). OISE/UT Open Access Policy Statement. Retrieved from http://www.oise.utoronto.ca/research/UserFiles/File/OA_Policy.pdf

Reporter. (2014, J anuary). MOOC on Mobiles for Development. COL News. Retrieved fromhttp:// www.col.org/ progServ/ programmes/ KM/ Pages/MOOCM4D.aspx

Rogers, E. (2003). Diffusion of innovations. New York: Free Press.

Siemens, G. (2012). MOOCs are really a platform. Elearnspace. Retrieved from http:// www.elearnspace.org/blog/2012/07/25/ moocs-are-really-a-platform/ 
Scassa, T. (2012). Canada's New Draft Open Government Licence. E-Commerce \& Internet Law. Retrieved from http://www.teresascassa.ca/index.php?option=com_k2\&view=item\&id=113:cana das-new-draft-open-government-licence $\&$ Itemid $=83$

Tamburri, R. (2014, February 12). An interview with Canadian MOOC pioneer George Siemens. University Affairs. Retrieved from http:// www.universityaffairs.ca/an-interview-withcanadian-mooc-pioneer-george-siemens.aspx

University of Alberta. (2013). Dino101: Dinosaur paleobiology. Retrieved fromhttp:// uofa.ualberta.ca/ courses/dino101

van der Vaart, L. (2013). e-InfraNet: 'Open' as the default modus operandi for research and higher education. (M. V. Berchum, R. Bruce, M. Burgess, G. Hanganu, N. J acobs, D. Lecarpentier, S. Pinfield \&P. Stokes (Eds.)), Retrieved from http:// www.surf.nl/nl/publicaties/ Documents/e-InfraNet-Open-as-the-Default-ModusOperandi-for-Research-and-Higher-Education.pdf

Weller, M. (2014). The battle for open: How openness won and why it doesn't feel like victory. Retrieved from $\underline{\text { htp: }: / / d x . d o i . o r g / 10.5334 / b a m}$

Yuan, L. and Powell, S. (2013). MOOCs and open education: Implications for higher education. CETIS White Paper. Retrieved from http:// publications.cetis.ac.uk/ 2013/667

(C) McGreal, Anderson, and Conrad

\section{Athabasca University $\mathbf{A}$}

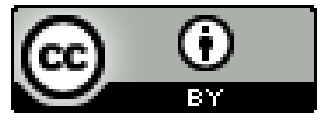

